\title{
Report（報 告)
}

\section{フクロウ目の新しい種和名}

\author{
山崎剛史 ${ }^{1, *}$ ・亀谷辰 朗 $^{1} \cdot$ 太田紀子 ${ }^{1}$
}

\section{Revised Japanese Names for Species of Owls (Strigiformes)}

\author{
Takeshi Yamasaki ${ }^{1,}$ *, Tatsuaki Kameya ${ }^{1}$ and Noriko Ota ${ }^{1}$
}

\begin{abstract}
Japanese names are a useful tool for Japanese speakers to communicate about birds. However, over 30 years have already passed since the most influential book treating all modern birds and providing Japanese names, "A World List of Birds" (Yamashina 1986), was published. During that time, the classification of birds has undergone major changes. Here we provide a revised list of Japanese names of owl species (Strigiformes) which adopts the latest classification system (Gill \& Donsker 2017). When compiling our list, we paid attention to ensuring the stability, brevity and correctness of Japanese names.
\end{abstract}

Key words: Japanese names, Owls, Species, Strigiformes.

キーワード：和名，フクロウ類，種，フクロウ目.

\section{はじめに}

鳥の種に付けられた名称のうち, 科学的議論に最も適しているのは学名である。それは『国 際動物命名規約』（動物命名法国際審議会 2005）による厳しい規制を受けているため，ある一つ の種に対して多くの別名があるなどの難しい事態のときでさえ, 正しい名称が客観的に, 一意 に定まる（詳しくは, 山崎 2007）。これに対し, 学名以外のすべての名称は通俗名と総称され る。通俗名は学名とは違って規約による規制を受けないが，ラテン語（あるいはラテン語化さ れた他言語）ではなく，慣れ親しんだ母国語を基礎とした名称の体系を構築できるという明ら かな利点があるため，多くの国において整備が進められ，日常的に用いられている。和名につ いては，森岡（1980,1981, 1982, 1983）, 山階（1986），白井（1992）などが整備を行った。

これらの試みのなかで，特筆に值するものは『世界鳥類和名辞典』（山階 1986）である。こ れは，世界に分布するすべての鳥類を網羅したはじめての和名リストで，1冊の書籍として出 版・販売されたため, 各方面に強い影響力を持つに至った。しかし, この書籍が出版されてか ら, すでに 30 年が経過している。この間, 分子系統学が目覚ましい発展を遂げたこと, 生物

Received 6 June 2017.

1 公益財団法人山階鳥類研究所， $=270-1145$ 千葉県我孫子市高野山 115.

* 責任著者. E-mail: yamasaki@yamashina.or.jp

1 Yamashina Institute for Ornithology, 115 Konoyama, Abiko, Chiba 270-1145, Japan.

* Corresponding author. E-mail: yamasaki@yamashina.or.jp 
音響学についてもデータの蓄積が進んだことなどを受け，鳥類の分類体系は大きく変化した。 例えば，山階（1986）において1種として扱われていた種が複数に分割されたり，所属する属 が変化したりした例は非常に多い。このため, 山階（1986）に掲載されていない学名の数は増 えたし，また，学名が掲載されていた場合にも，そこで与えられた和名が適切でなくなった例 が多く見られるようになった。例えば，山階（1986）はCiconia ciconiaに「コウノトリ」とい う和名を与えた。この鳥の東アジアの集団は現在では独立種C. boyciana として扱われ，C. ciconia はユーラシア大陸西部にのみ分布する鳥だとされる。したがって，C. ciconiaを「コウ ノトリ」と呼ぶのはもはや適切でない。

このような背景のもと, 我々は, 山階（1986）の和名の体系をアップデートする計画に取り組 んできた。我々は, 多数の著名な分子系統学者の協力のもと, 内容の確認, 更新が定期的かつ 頻繁に行われている Gill \& Donsker（2017）を最新の分類体系として採用し，そこに登場するす べての種に適切な和名を与えることにした。とくに以下の2点に留意し，この作業を進めた。

1. 安定性。すでに広く用いられている和名は, 安易に変えるべきではない。この方針の遵守 には, 分類学的変遷の知識が欠かせない。例えば, 属の移動や, それに伴って生じる同名関係 解消のための置換名使用は，学名を変えるが，それが指す実体は同じままである。この場合， その種に対する和名は，同じものを使うべきである。

2. 表現の簡潔性と正確性。和名中の形容詞的要素（例えば,「アジア」「シロ」など）は不必 要に（圥長に）用いるべきではないし，用いるときにはその鳥の特性を正確に表すべきであ る。この点は, 後述の通り, 種の分割があった際, とくに問題になる。

ここでは，フクロウ目S Strigiformesの種について，作業を進めた結果を公表する。

\section{方法}

以下, 山階（1986）の和名を山階和名, ここで提唱する新リストの和名を新和名（文献調査 に由来するものがあるので, 必ずしも新称とは限らない）と呼ぶ。新和名の決定手順は以下の 通りである。なお, 絶滅鳥については, 基本的には本稿の対象外としたが, 山階（1986）に収 録されているワライフクロウSceloglaux albifaciesについては検討を行った。

\section{A. Gill \& Donsker (2017) の学名が山階（1986）に掲載されていない場合}

この場合にはまず del Hoyo \& Collar（2014）の種分類のレビューを確認した。そのうえで,

（A-1）当該の種が，山階（1986）が採用した分類体系が構築された時期以降に, 他種から分 割されたのではなく, まったくの新種として記載されたものだと考えられるときには, 日本鳥 学会 (1942), 黒田 (1964), 山階鳥類研究所 (1976), 内田・島崎 (1987), 白井 (1992), 荒 俣（1993），日本鳥学会（2012），柴田（2015）を調査し，すでに和名が提唱されているかどう かを確認した。提唱された和名がある場合には，それらすべてを新和名の候補とした。和名の 提唱が行われていないときには，新和名候補なしとした。

（A-2）当該の種が，山階（1986）掲載の種の分割（亜種の格上げや, 亜種の記載を介さない 隠蔽種の発見）によるものであった場合には，後述の「種の分割に関連する新和名候補選定手 
順」に基づいて新和名候補を探索した。

（A-3）当該の種が, 山階（1986）掲載の種の属の移動, 置換名の使用などによって学名が変 化したものであった場合には，その種の山階和名を新和名の候補とした。

\section{B. Gill \& Donsker（2017）の学名が山階（1986）に掲載されている場合} この場合には，Gill \& Donsker（2017）と山階（1986）の分布を比較した。

（B-1）分布の一致が見られるときには，両文献がその学名で表している種の実体は同じである と考えた。この場合, その山階和名を新和名の候補とした。

（B-2）分布が異なるときには，学名が同じであっても，一部の亜種の格上げや，種の統合な ど, 分類学的な変更が加えられている可能性が高いと判断した。この場合には, del Hoyo \& Collar（2014）の種分類のレビューを参照することで, 分類学的変遷を把握した。そのうえで,

（B-2-a）分布の齟䶣が種の分割（亜種の格上げや，亜種の記載を介さない隠蔽種の発見）に よる場合には, 後述の「種の分割に関連する新和名候補選定手順」に基づいて新和名候補を 決定した。

（B-2-b）分布の齟䶣が複数種の統合による場合には，それらの種の山階和名をすべて新和名 の候補にした。

なお, 分布の齟䶚が種の分割, 統合以外の分類学的変更によって生じた例（例えば, スズメ 目のモウコアカモズLanius isabellinus; Pearson 2000, Pearson et al. 2012）は，フクロウ目につい ては見られなかった。

\section{種の分割に関連する新和名候補選定手順}

ある種が複数の種に分割されたとき, 従来の山階和名をどちらの種に適用するかは, 以下の 規則に従って判断した。

\section{（1）分割後の種のなかに日本産の種が含まれる場合}

分割後の種のなかに日本産のもの（外来種を含む）が含まれていて, それが 1 種だけの場合 には, その種の新和名候補として, 従来の山階和名を採用した。日本産のものが複数ある場合 には, 日本鳥学会（2012）の種和名（同書で当該の種が亜種扱いの場合には亜種和名）の付け 方にならい, 従来の山階和名を新和名候補とする種を決めた。その他の日本産の種の新和名候 補には, 日本鳥学会（2012）の種和名または亜種和名を用いた。海外のものについては, 日本 鳥学会 (1942), 黒田 (1964), 山階鳥類研究所 (1976), 内田・島崎 (1987), 白井 (1992), 荒俣（1993）, 日本鳥学会（2012）のAppendix B「検討中の種・亜種」, 柴田（2015）で和名が 付けられているかどうかを確認し，付けられていた場合にはそれらすべてを新和名の候補とし 
た。和名の提唱が行われていないときには，新和名候補なしとした。なお，これらの文献が， 当該の種を亜種扱いしたうえでそれに和名を与えていた場合には，その亜種和名も当該の種の 新和名の候補とした。

\section{（2）分割後の種がすべて海外産の場合}

（2-1）分割前の種の山階和名が表現型を表す言葉や, 地名, 人名等を含む場合には, それが表 すところと最もよく一致する種の新和名候補として, その山階和名を採用した。その他の種に ついては，(1）の海外産の種の手順を踏襲した。

（2-2）（2-1）が適用できない場合で, 分割された種が広域に分布するもの1種とその他, 局所 的な分布を持つ種からなるときには, その広域分布種の新和名候補として, 山階和名を用い た。ただし, 後者の局所的な分布を持つ種のなかに樺太・朝鮮半島・台湾・南洋諸島に分布す る種が含まれている場合には, 歴史的な観点から見て, 広域分布種ではなく, それらの種が山 階和名を引き継ぐ方が妥当である例も見られた。この場合には，それらの種の新和名候補とし て, 山階和名を用いた。なお, この判断を行う際には, 日本鳥学会（1942）を参考にした。山 階和名を新和名候補として引き継いだ種以外の種については，(1）の海外産の種の手順を踏襲 した。

（2-3）上記2つの基準の適用がいずれも難しい場合には, 最も古くに記載された学名を持つ種 の新和名候補として, 分割前の山階和名を用いた。その他の種については, (1) の海外産の種 の手順を踏襲した。

\section{新和名の確定方法}

Gill \& Donsker（2017）の学名に対し，上記の手順で新和名候補が確定したものについては, 誤字・脱字, 地名や人名のカタカナ表記の不統一を含んでいないか確認し, 問題があるときに は適宜修正を加えた。その和名候補が表現型・分布等を表す言葉を含む場合には, それが実体 に即しているかどうかを確認し，不適切な場合にはその候補を却下した。差別的な用語を含む ものも同様にした。最後に口調と文字数についても検討し, 使用に耐えないと思われるものは 却下した（例えば，既存の種の分割による種のなかには，非常に長い新和名候補を持つものが 散見された)。

以上により，候補が1つに絞り込まれた場合にはそれを新和名として採用した。候補が複数 残っている場合には，その鳥の実体を最もよく表しており，口調と文字数の点でも好ましいと 判断されるものを新和名として採用した。甲乙がつけ難い場合については，どの和名がより普 及しているか（普及の度合いは，ウェブ検索（http://google.co.jp；2017年6月6日アクセス）に よるヒット数で測定した), どの和名の提唱が先かについても勘案し, 新和名を決定した。な お，新和名として，山階和名を踏襲することになった種のなかには，普及した別和名を持つも のも見られた。それらについては，別和名をかっこに入れて併記した。

（1）新和名の候補がないか，あるいは，（2）上記の手順を踏んだ結果としてすべての候補が 却下され，新和名が確定しないときには，ここで新たに和名を考案することにした。以下， 
（1）の場合を「新称」，（2）の場合を「改称」とよぶ。

\section{結果}

フクロウ目239種の新しい種和名を付表 1 に示した。なお，方法の各々の場合分けに対応す る種数内訳は以下の通りであった。

（A-1）まったくの新種として記載されたもの 21 種（8.8\%）。（A-2）既存の種の分割によって生 じたもの 75 種（31.4\%)。（A-3）属の移動があった種28種（11.7\%）（なお，属の移動と種の分 割の両方を経た種は，A-2に含めた)。置換名が使用されたものは，ニューアイルランドアオ バズク Ninox variegata（山階（1986）ではN. solomonis）と，チャバラアオバズク N. ochracea （山階（1986）ではN. perversa）の2種（0.8\%)。（B-1）学名と分布が不変であったもの 81 種 (33.9\%)。(B-2-a）学名は同じだが，分布が狭まったもの32種（13.4\%)。（B-2-b）学名が同じ で分布が広がったものは, フクロウ目においては見られなかった。なお，ここで新たに和名を 考案した種は, 新称 56 種 $(23.4 \%)$, 改称 13 種 (5.4\%) であった。

\section{謝 辞}

この原稿を取りまとめるにあたっては, 山階鳥類研究所自然誌研究室の鶴見みや古氏, 今村 知子氏からご支援をいただいた。本研究は, 文部科学省科学研究費補助金特定奨励費 (平成 27〜29年度）の交付を受けて実施された。

\section{引用文献}

荒俣 宏 1993. 世界大博物図鑑別巻1 [絶滅・希少鳥類]. 平凡社, 東京.

動物命名法国際審議会 2005. 国際動物命名規約第4版 日本語版〔追補〕日本分類学会連合, 東京.

Gill, F. \& Donsker, D. (eds.) 2017. IOC World Bird List (v 7.2). doi: 10.14344/IOC.ML.7.2. accessed on 2 June 2017.

del Hoyo, J. \& Collar, N. J. 2014. HBW and BirdLife International Illustrated Checklist of the Birds of the World. Volume 1: Non-passerines. Lynx Edicions, Barcelona.

黒田長久 1964. アフリカの鳥 20. アフリカ4(7): 32-33.

森岡弘之 1980. 世界の鳥の分類和名(1). 鳥 29: 99-102.

森岡弘之 1981. 世界の鳥の分類和名(2). 鳥 30: 95-104.

森岡弘之 1982. 世界の鳥の分類和名(3). 鳥 31:25-31.

森岡弘之 1983. 世界の鳥の分類和名(4). 鳥 32:161-173.

日本鳥学会(編) 1942. 日本鳥類目録 (改訂三版). 日本鳥学会, 東京.

日本鳥学会 2012. 日本鳥類目録改訂第7版. 日本鳥学会, 三田.

Pearson, D. 2000. The races of the Isabelline Shrike Lanius isabellinus and their nomenclature. Bulletin of the British Ornithologists' Club 120 (1) : 22-33.

Pearson, D., Svensson, L. \& Frahnert, S. 2012. Further on the type series and nomenclature of the Isabelline Shrike Lanius isabellinus. Bulletin of the British Ornithologists' Club 132 (4) : 270-276.

柴田佳秀 2015. 生きもの好きの自然ガイド「このは」No. 9 世界のフクロウがわかる本とっておきの 100 種. 文一総合出版, 東京.

白井祥平 1992. 世界鳥類名検索辞典・和名篇. 原書房, 東京.

内田清一郎・島崎三郎 1987. 鳥類学名辞典. 東京大学出版会, 東京.

山崎剛史 2007. 鳥類の保全と分類学. 保全鳥類学 (山階鳥類研究所編), pp. 13-31. 京都大学学術出版会, 京都.

山階鳥類研究所 1976. 世界の鳥の和名ソビエット連邦の鳥. 山階鳥類研究所, 東京.

山階芳麿 1986. 世界鳥類和名辞典. 大学書林, 東京. 
付表1．新たに提案したフクロウ目和名リスト．分類と英名はGill \& Donsker（2017）に準拠した。「改 称」は, 山階（1986）掲載の和名を一部改変（地名のカタカナ表記など）したものを指す。

Appendix 1. A newly proposed list of Japanese names for species of owls (Strigiformes). The classification and English names follow Gill \& Donsker (2017).

\begin{tabular}{|c|c|c|c|c|c|}
\hline No. & $\begin{array}{c}\text { 英名 } \\
\text { English name }\end{array}$ & $\begin{array}{c}\text { 学名 } \\
\text { Scientific name }\end{array}$ & $\begin{array}{c}\text { 和名 } \\
\text { Japanese name }\end{array}$ & & $\begin{array}{l}\text { 典 } \\
\text { arce }\end{array}$ \\
\hline 1 & Greater Sooty Owl & Tyto tenebricosa & ススイロメンフクロウ & & \\
\hline 2 & Lesser Sooty Owl & Tyto multipunctata & ヒメススイロメンフクロウ & 柴田（2015） & より \\
\hline 3 & Minahassa Masked Owl & Tyto inexspectata & ミナハサメンフクロウ & & \\
\hline 4 & Taliabu Masked Owl & Tyto nigrobrunnea & スラメンフクロウ & & \\
\hline 5 & Moluccan Masked Owl & Tyto sororcula & モルッカメンフクロウ & 新称 & \\
\hline 6 & Manus Masked Owl & Tyto manusi & マヌスメンフクロウ & 新称 & \\
\hline 7 & Golden Masked Owl & Tyto aurantia & ニューブリテンメンフクロウ & & \\
\hline 8 & Australian Masked Owl & Tyto novaehollandiae & オオメンフクロウ & & \\
\hline 9 & Sulawesi Masked Owl & Tyto rosenbergii & セレベスメンフクロウ & & \\
\hline 10 & Red Owl & Tyto soumagnei & マダガスカルメンフクロウ & & \\
\hline 11 & Western Barn Owl & Tyto alba & メンフクロウ & & \\
\hline 12 & American Barn Owl & Tyto furcata & アメリカメンフクロウ & 新称 & \\
\hline 13 & Eastern Barn Owl & Tyto javanica & オーストラリアメンフクロウ & 新称 & \\
\hline 14 & Andaman Masked Owl & Tyto deroepstorffi & アンダマンメンフクロウ & 新称 & \\
\hline 15 & Ashy-faced Owl & Tyto glaucops & ヒスパニョラメンフクロウ & 柴田（2015） & を改称 \\
\hline 16 & African Grass Owl & Tyto capensis & ミナミメンフクロウ & & \\
\hline 17 & Eastern Grass Owl & Tyto longimembris & ヒガシメンフクロウ & & \\
\hline 18 & Congo Bay Owl & Phodilus prigoginei & コンゴニセメンフクロウ & & \\
\hline 19 & Oriental Bay Owl & Phodilus badius & ニセメンフクロウ & & \\
\hline 20 & Sri Lanka Bay Owl & Phodilus assimilis & セイロンニセメンフクロウ & 新称 & \\
\hline 21 & Giant Scops Owl & Otus gurneyi & オニコノハズク & & \\
\hline 22 & White-fronted Scops Owl & Otus sagittatus & ハナジロコノハズク & & \\
\hline 23 & Reddish Scops Owl & Otus rufescens & アカチャコノハズク & & \\
\hline 24 & Serendib Scops Owl & Otus thilohoffmanni & セイロンコノハズク & 新称 & \\
\hline 25 & Sandy Scops Owl & Otus icterorhynchus & アカヒメコノハズク & & \\
\hline 26 & Sokoke Scops Owl & Otus ireneae & ハイイロコノハズク & & \\
\hline 27 & Andaman Scops Owl & Otus balli & アンダマンコノハズク & & \\
\hline 28 & Flores Scops Owl & Otus alfredi & フロレスコノハズク & & \\
\hline 29 & Mountain Scops Owl & Otus spilocephalus & タイワンコノハズク & & \\
\hline 30 & Rajah Scops Owl & Otus brookii & ラジャーオオコノハズク & & \\
\hline 31 & Javan Scops Owl & Otus angelinae & ジャワコノハズク & 荒俣（1993） & より \\
\hline 32 & Mentawai Scops Owl & Otus mentawi & ムンタワイオオコノハズク & 柴田（2015） & を改称 \\
\hline 33 & Indian Scops Owl & Otus bakkamoena & インドオオコノハズク & 柴田（2015） & より \\
\hline 34 & Collared Scops Owl & Otus lettia & チャメオオコノハズク & 新称 & \\
\hline 35 & Japanese Scops Owl & Otus semitorques & オオコノハズク & & \\
\hline 36 & Sunda Scops Owl & Otus lempiji & スンダオオコノハズク & 柴田（2015） & より \\
\hline 37 & Palawan Scops Owl & Otus fuliginosus & パラワンオオコノハズク & 柴田（2015） & より \\
\hline 38 & Philippine Scops Owl & Otus megalotis & ルソンオオコノハズク & & \\
\hline 39 & Everett's Scops Owl & Otus everetti & ミンダナオオオコノハズク & 新称 & \\
\hline 40 & Negros Scops Owl & Otus nigrorum & ネグロスオオコノハズク & 新称 & \\
\hline 41 & Wallace's Scops Owl & Otus silvicola & フロレスオオコノハズク & & \\
\hline 42 & Mindanao Scops Owl & Otus mirus & ミンダナオコノハズク & 柴田（2015） & より \\
\hline 43 & Luzon Scops Owl & Otus longicornis & ルソンコノハズク & 白井（1992） & より \\
\hline 44 & Mindoro Scops Owl & Otus mindorensis & ミンドロコノハズク & 白井（1992） & より \\
\hline 45 & Pallid Scops Owl & Otus brucei & サバクコノハズク & $\begin{array}{l}\text { 山階鳥類研 } \\
\text { を改称 }\end{array}$ & 究所（1976） \\
\hline 46 & African Scops Owl & Otus senegalensis & アフリカコノハズク & & \\
\hline 47 & Arabian Scops Owl & Otus pamelae & アラビアコノハズク & 新称 & \\
\hline
\end{tabular}


付表1.つづき.

Appendix 1. Continued.

\begin{tabular}{|c|c|c|c|c|}
\hline No. & $\begin{array}{c}\text { 英名 } \\
\text { English name }\end{array}$ & $\begin{array}{c}\text { 学名 } \\
\text { Scientific name }\end{array}$ & $\begin{array}{c}\text { 和名 } \\
\text { Japanese name }\end{array}$ & $\begin{array}{l}\text { 出典 } \\
\text { Source }\end{array}$ \\
\hline 48 & Eurasian Scops Owl & Otus scops & ヨーロッパコノハズク & \\
\hline 49 & Cyprus Scops Owl & Otus cyprius & キプロスコノハズク & 新称 \\
\hline 50 & Oriental Scops Owl & Otus sunia & コノハズク & \\
\hline 51 & Socotra Scops Owl & Otus socotranus & ソコトラコノハズク & 新称 ～～～～～～ \\
\hline 52 & Moluccan Scops Owl & Otus magicus & モルッカコノハズク & 柴田（2015）より \\
\hline 53 & Rinjani Scops Owl & Otus jolandae & リンジャニコノハズク & 新称 ～～～～～～ \\
\hline 54 & Sula Scops Owl & Otus sulaensis & スラコノハズク & 新称 \\
\hline 55 & Siau Scops Owl & Otus siaoensis & シアウコノハズク & 新称 \\
\hline 56 & Mantanani Scops Owl & Otus mantananensis & マンタナニコノハズク & 新称 \\
\hline 57 & Ryukyu Scops Owl & Otus elegans & リュウキュウコノハズク & 日本鳥学会 (2012) より \\
\hline 58 & Sulawesi Scops Owl & Otus manadensis & セレベスコノハズク & \\
\hline 59 & Sangihe Scops Owl & Otus collari & サンギヘコノハズク & 新称 \\
\hline 60 & Biak Scops Owl & Otus beccarii & ビアクコノハズク & \\
\hline 61 & Seychelles Scops Owl & Otus insularis & セーシェルコノハズク & \\
\hline 62 & Simeulue Scops Owl & Otus umbra & シムルエコノハズク & 改称 \\
\hline 63 & Enggano Scops Owl & Otus enganensis & エンガノコノハズク & 白井（1992）より \\
\hline 64 & Nicobar Scops Owl & Otus alius & ニコバルコノハズク & 新称 \\
\hline 65 & Pemba Scops Owl & Otus pembaensis & ペンバコノハズク & 柴田（2015）を改称 \\
\hline 66 & Karthala Scops Owl & Otus pauliani & グランドコモロコノハズク & 荒俣（1993）を改称 \\
\hline 67 & Anjouan Scops Owl & Otus capnodes & アンジュアンコノハズク & 新称 \\
\hline 68 & Moheli Scops Owl & Otus moheliensis & モヘリコノハズク & 新称 \\
\hline 69 & Mayotte Scops Owl & Otus mayottensis & マヨットコノハズク & 新称 \\
\hline 70 & Torotoroka Scops Owl & Otus madagascariensis & オナガマダガスカルコノハズク & 新称 \\
\hline 71 & Rainforest Scops Owl & Otus rutilus & マダガスカルコノハズク & \\
\hline 72 & Sao Tome Scops Owl & Otus hartlaubi & サントメコノハズク & \\
\hline 73 & Flammulated Owl & Psiloscops flammeolus & アメリカコノハズク & \\
\hline 74 & Eastern Screech Owl & Megascops asio & アメリカオオコノハズク & \\
\hline 75 & Western Screech Owl & Megascops kennicottii & ニシアメリカオオコノハズク & 柴田（2015）より \\
\hline 76 & Balsas Screech Owl & Megascops seductus & バルサスオオコノハズク & 柴田（2015）より \\
\hline 77 & Pacific Screech Owl & Megascops cooperi & クーパーオオコノハズク & 改称 \\
\hline 78 & Whiskered Screech Owl & Megascops trichopsis & ヒゲコノハズク & \\
\hline 79 & Tropical Screech Owl & Megascops choliba & スピックスコノハズク & \\
\hline 80 & West Peruvian Screech Owl & Megascops roboratus & シロエリオオコノハズク & \\
\hline 81 & Koepcke's Screech Owl & Megascops koepckeae & ケプケオオコノハズク & 新称 \\
\hline 82 & Bare-shanked Screech Owl & Megascops clarkii & パナマオオコノハズク & \\
\hline 83 & Bearded Screech Owl & Megascops barbarus & ヒゲオオコノハズク & \\
\hline 84 & Rufescent Screech Owl & Megascops ingens & アンデスオオコノハズク & \\
\hline 85 & Colombian Screech Owl & Megascops colombianus & コロンビアオオコノハズク & 柴田（2015）より \\
\hline 86 & Cinnamon Screech Owl & Megascops petersoni & ニッケイコノハズク & 新称 \\
\hline 87 & Cloud-forest Screech Owl & Megascops marshalli & アンデスコノハズク & 白井（1992）より \\
\hline 88 & Tawny-bellied Screech Owl & Megascops watsonii & チャバラオオコノハズク & \\
\hline 89 & Middle American Screech Owl & Megascops guatemalae & キタホソジマオオコノハズク & 改称 \\
\hline 90 & Vermiculated Screech Owl & Megascops vermiculatus & ホソジマオオコノハズク & 内田・島崎（1987）より \\
\hline 91 & Roraiman Screech Owl & Megascops roraimae & ロライマオオコノハズク & 新称 \\
\hline 92 & Choco Screech Owl & Megascops centralis & チョコオオコノハズク & 新称 \\
\hline 93 & Napo Screech Owl & Megascops napensis & ナポオオコノハズク & 新称 \\
\hline 94 & Yungas Screech Owl & Megascops hoyi & ユンガスオオコノハズク & 新称 \\
\hline 95 & Black-capped Screech Owl & Megascops atricapilla & ズグロオオコノハズク & \\
\hline 96 & Long-tufted Screech Owl & Megascops sanctaecatarinae & ミミナガオオコノハズク & 柴田（2015）より \\
\hline 97 & Puerto Rican Screech Owl & Megascops nudipes & プエルトリコオオコノハズク & \\
\hline
\end{tabular}


付表1.つづき.

Appendix 1. Continued.

\begin{tabular}{|c|c|c|c|c|}
\hline No. & $\begin{array}{c}\text { 英名 } \\
\text { English name }\end{array}$ & $\begin{array}{c}\text { 学名 } \\
\text { Scientific name }\end{array}$ & $\begin{array}{c}\text { 和名 } \\
\text { Japanese name }\end{array}$ & $\begin{array}{l}\text { 出典 } \\
\text { Source }\end{array}$ \\
\hline 98 & White-throated Screech Owl & Megascops albogularis & ノドジロオオコノハズク & \\
\hline 99 & Palau Owl & Pyrroglaux podargina & カキイロコノハズク & \\
\hline 100 & Bare-legged Owl & Margarobyas lawrencii & ユビナガフクロウ & \\
\hline 101 & Northern White-faced Owl & Ptilopsis leucotis & アフリカオオコノハズク & \\
\hline 102 & Southern White-faced Owl & Ptilopsis granti & ミナミアフリカオオコノハズク & 柴田（2015）より \\
\hline 103 & Snowy Owl & Bubo scandiacus & シロフクロウ & \\
\hline 104 & Great Horned Owl & Bubo virginianus & アメリカワシミミズク & \\
\hline 105 & Lesser Horned Owl & Bubo magellanicus & マゼランワシミミズク & 柴田（2015）より \\
\hline 106 & Eurasian Eagle-Owl & Bubo bubo & ワシミミズク & \\
\hline 107 & Indian Eagle-Owl & Bubo bengalensis & ベンガルワシミミズク & 新称 \\
\hline 108 & Pharaoh Eagle-Owl & Bubo ascalaphus & サバクワシミミズク & 黒田（1964）より \\
\hline 109 & Cape Eagle-Owl & Bubo capensis & イワワシミミズク & \\
\hline 110 & Spotted Eagle-Owl & Bubo africanus & アフリカワシミミズク & \\
\hline 111 & Greyish Eagle-Owl & Bubo cinerascens & ハイイロワシミミズク & 新称 \\
\hline 112 & Fraser's Eagle-Owl & Bubo poensis & コヨコジマワシミミズク & \\
\hline 113 & Usambara Eagle-Owl & Bubo vosseleri & ウサンバラワシミミズク & 荒俣（1993）を改称 \\
\hline 114 & Spot-bellied Eagle-Owl & Bubo nipalensis & ネパールワシミミズク & \\
\hline 115 & Barred Eagle-Owl & Bubo sumatranus & マレーワシミミズク & \\
\hline 116 & Shelley's Eagle-Owl & Bubo shelleyi & ヨコジマワシミミズク & \\
\hline 117 & Verreaux's Eagle-Owl & Bubo lacteus & クロワシミミズク & \\
\hline 118 & Dusky Eagle-Owl & Bubo coromandus & ウスグロワシミミズク & \\
\hline 119 & Akun Eagle-Owl & Bubo leucostictus & アクンワシミミズク & \\
\hline 120 & Philippine Eagle-Owl & Bubo philippensis & フィリピンワシミミズク & \\
\hline 121 & Blakiston's Fish Owl & Bubo blakistoni & シマフクロウ & \\
\hline 122 & Brown Fish Owl & Ketupa zeylonensis & ミナミシマフクロウ & \\
\hline 123 & Tawny Fish Owl & Ketupa flavipes & ウオミミズク & \\
\hline 124 & Buffy Fish Owl & Ketupa ketupu & マレーウオミミズク & \\
\hline 125 & Pel's Fishing Owl & Scotopelia peli & ウオクイフクロウ & \\
\hline 126 & Rufous Fishing Owl & Scotopelia ussheri & アカウオクイフクロウ & \\
\hline 127 & Vermiculated Fishing Owl & Scotopelia bouvieri & タテジマウオクイフクロウ & \\
\hline 128 & Spotted Wood Owl & Strix seloputo & マレーモリフクロウ & \\
\hline 129 & Mottled Wood Owl & Strix ocellata & インドモリフクロウ & \\
\hline 130 & Brown Wood Owl & Strix leptogrammica & オオフクロウ & \\
\hline 131 & Tawny Owl & Strix aluco & モリフクロウ & \\
\hline 132 & Himalayan Owl & Strix nivicolum & ミヤマモリフクロウ & 新称 \\
\hline 133 & Omani Owl & Strix butleri & ウスイロモリフクロウ & \\
\hline 134 & Desert Owl & Strix hadorami & サバクフクロウ & 新称 \\
\hline 135 & Spotted Owl & Strix occidentalis & ニシアメリカフクロウ & \\
\hline 136 & Barred Owl & Strix varia & アメリカフクロウ & \\
\hline 137 & Cinereous Owl & Strix sartorii & メキシコフクロウ & 新称 \\
\hline 138 & Fulvous Owl & Strix fulvescens & チュウベイフクロウ & 新称 \\
\hline 139 & Rusty-barred Owl & Strix hylophila & ブラジルモリフクロウ & \\
\hline 140 & Chaco Owl & Strix chacoensis & チャコモリフクロウ & 新称 \\
\hline 141 & Rufous-legged Owl & Strix rufipes & アカアシモリフクロウ & \\
\hline 142 & Ural Owl & Strix uralensis & フクロウ & \\
\hline 143 & Pere David's Owl & Strix davidi & シセンフクロウ & \\
\hline 144 & Great Grey Owl & Strix nebulosa & カラフトフクロウ & \\
\hline 145 & African Wood Owl & Strix woodfordii & アフリカヒナフクロウ & \\
\hline 146 & Mottled Owl & Strix virgata & ナンベイヒナフクロウ & \\
\hline 147 & Rufous-banded Owl & Strix albitarsis & アカオビヒナフクロウ & \\
\hline
\end{tabular}


付表1。つづき。

Appendix 1. Continued.

\begin{tabular}{|c|c|c|c|c|}
\hline No. & $\begin{array}{c}\text { 英名 } \\
\text { English name }\end{array}$ & $\begin{array}{c}\text { 学名 } \\
\text { Scientific name }\end{array}$ & $\begin{array}{c}\text { 和名 } \\
\text { Japanese name }\end{array}$ & $\begin{array}{l}\text { 出典 } \\
\text { Source }\end{array}$ \\
\hline 148 & Black-and-white Owl & Strix nigrolineata & シロクロヒナフクロウ & \\
\hline 149 & Black-banded Owl & Strix huhula & クロオビヒナフクロウ & \\
\hline 150 & Maned Owl & Jubula lettii & タテガミズク & \\
\hline 151 & Crested Owl & Lophostrix cristata & $\begin{array}{l}\text { ミミナガフクロウ } \\
\text { (カンムリズク) }\end{array}$ & $\begin{array}{l}\text { 普及度に基づき，山階 } \\
\text { （1986）の別和名併記の } \\
\text { 順序を入れ替え }\end{array}$ \\
\hline 152 & Spectacled Owl & Pulsatrix perspicillata & メガネフクロウ & \\
\hline 153 & Tawny-browed Owl & Pulsatrix koeniswaldiana & キマユメガネフクロウ & \\
\hline 154 & Band-bellied Owl & Pulsatrix melanota & アカオビメガネフクロウ & \\
\hline 155 & Northern Hawk-Owl & Surnia ulula & オナガフクロウ & \\
\hline 156 & Eurasian Pygmy Owl & Glaucidium passerinum & スズメフクロウ & \\
\hline 157 & Collared Owlet & Glaucidium brodiei & ヒメフクロウ & \\
\hline 158 & Pearl-spotted Owlet & Glaucidium perlatum & アフリカスズメフクロウ & \\
\hline 159 & Northern Pygmy Owl & Glaucidium californicum & ロッキースズメフクロウ & \\
\hline 160 & Mountain Pygmy Owl & Glaucidium gnoma & メキシコスズメフクロウ & 新称 \\
\hline 161 & Baja Pygmy Owl & Glaucidium hoskinsii & バハスズメフクロウ & 新称 \\
\hline 162 & Guatemalan Pygmy Owl & Glaucidium cobanense & グアテマラスズメフクロウ & 柴田（2015）より \\
\hline 163 & Costa Rican Pygmy Owl & Glaucidium costaricanum & コスタリカスズメフクロウ & 柴田（2015）より \\
\hline 164 & Andean Pygmy Owl & Glaucidium jardinii & アンデススズメフクロウ & \\
\hline 165 & Cloud-forest Pygmy Owl & Glaucidium nubicola & コロンビアスズメフクロウ & 新称 \\
\hline 166 & Yungas Pygmy Owl & Glaucidium bolivianum & ユンガススズメフクロウ & 新称 \\
\hline 167 & Colima Pygmy Owl & Glaucidium palmarum & コリマスズメフクロウ & 柴田（2015）より \\
\hline 168 & Tamaulipas Pygmy Owl & Glaucidium sanchezi & タマウリパススズメフクロウ & 新称 \\
\hline 169 & Pernambuco Pygmy Owl & Glaucidium mooreorum & ペルナンブコスズメフクロウ & 新称 \\
\hline 170 & Central American Pygmy Owl & Glaucidium griseiceps & チュウベイスズメフクロウ & 新称 \\
\hline 171 & Subtropical Pygmy Owl & Glaucidium parkeri & アネッタイスズメフクロウ & 柴田（2015）より \\
\hline 172 & Amazonian Pygmy Owl & Glaucidium hardyi & アマゾンスズメフクロウ & 新称 \\
\hline 173 & East Brazilian Pygmy Owl & Glaucidium minutissimum & コスズメフクロウ & \\
\hline 174 & Ferruginous Pygmy Owl & Glaucidium brasilianum & アカスズメフクロウ & \\
\hline 175 & Pacific Pygmy Owl & Glaucidium peruanum & ペルースズメフクロウ & 柴田（2015）より \\
\hline 176 & Austral Pygmy Owl & Glaucidium nana & ミナミスズメフクロウ & 柴田（2015）ょり \\
\hline 177 & Cuban Pygmy Owl & Glaucidium siju & キューバスズメフクロウ & \\
\hline 178 & Red-chested Owlet & Glaucidium tephronotum & ムネアカスズメフクロウ & \\
\hline 179 & Sjöstedt's Barred Owlet & Glaucidium sjostedti & セアカスズメフクロウ & \\
\hline 180 & Asian Barred Owlet & Glaucidium cuculoides & オオスズメフクロウ & \\
\hline 181 & Javan Owlet & Glaucidium castanopterum & ジャワスズメフクロウ & 白井（1992）より \\
\hline 182 & Jungle Owlet & Glaucidium radiatum & モリスズメフクロウ & \\
\hline 183 & Chestnut-backed Owlet & Glaucidium castanotum & クリセスズメフクロウ & 柴田（2015）より \\
\hline 184 & African Barred Owlet & Glaucidium capense & ヨコジマスズメフクロウ & \\
\hline 185 & Albertine Owlet & Glaucidium albertinum & コンゴスズメフクロウ & 新称 \\
\hline 186 & Long-whiskered Owlet & Xenoglaux loweryi & カオカザリヒメフクロウ & \\
\hline 187 & Elf Owl & Micrathene whitneyi & サボテンフクロウ & \\
\hline 188 & Little Owl & Athene noctua & コキンメフクロウ & \\
\hline 189 & Spotted Owlet & Athene brama & インドコキンメフクロウ & \\
\hline 190 & Burrowing Owl & Athene cunicularia & アナホリフクロウ & \\
\hline 191 & Forest Owlet & Heteroglaux blewitti & モリコキンメフクロウ & \\
\hline 192 & Boreal Owl & Aegolius funereus & キンメフクロウ & \\
\hline 193 & Northern Saw-whet Owl & Aegolius acadicus & $\begin{array}{r}\text { アメリカキンメフクロウ } \\
\text { (ヒメキンメフクロウ) }\end{array}$ & $\begin{array}{l}\text { 内田・島崎（1987）の和 } \\
\text { 名を併記 }\end{array}$ \\
\hline 194 & Unspotted Saw-whet Owl & Aegolius ridgwayi & メキシコキンメフクロウ & \\
\hline
\end{tabular}


付表 1 .つづき。

Appendix 1. Continued.

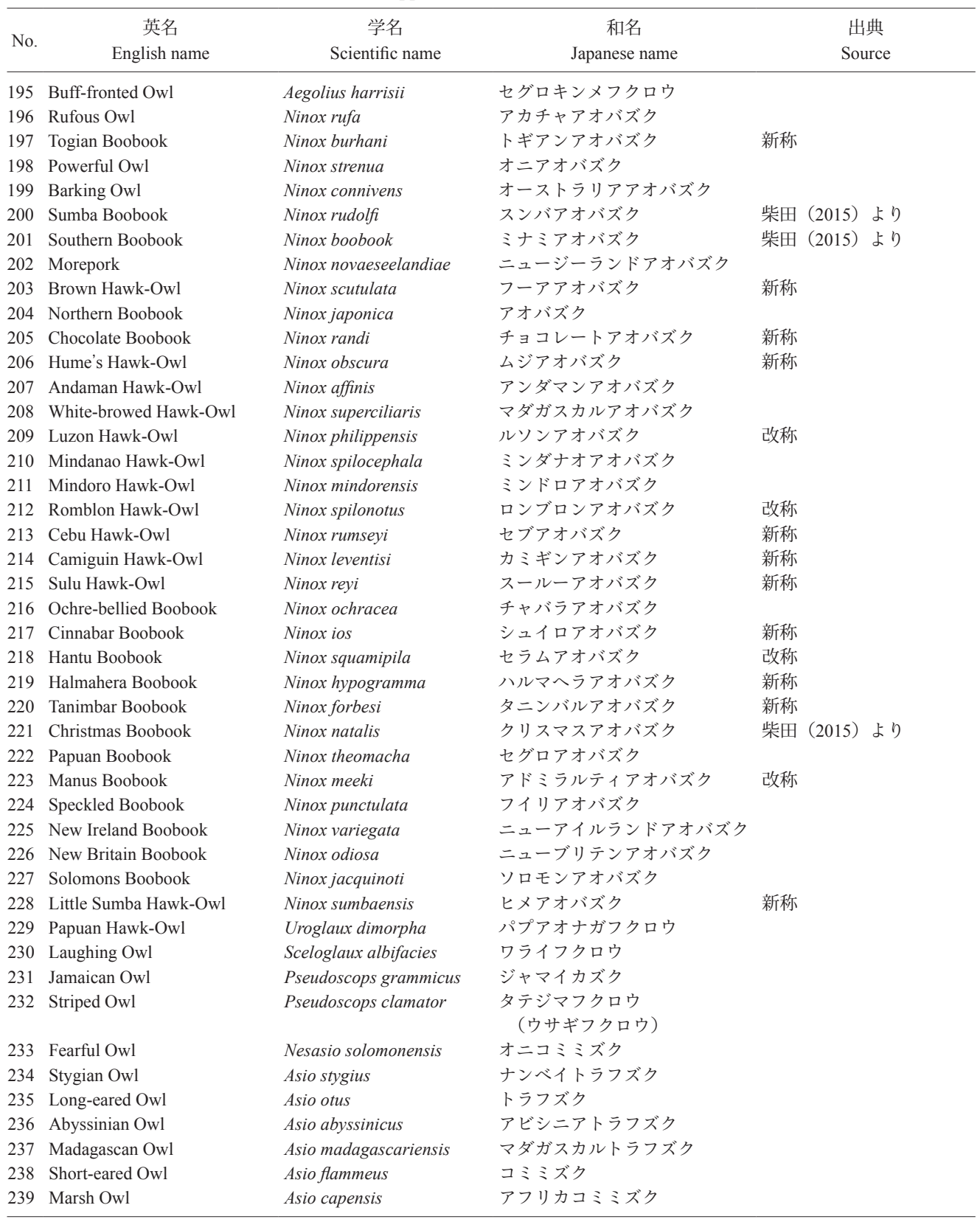

